\title{
Aging, nutrition and immunity - their relationship and interaction
}

\author{
Iftikhar Alam ${ }^{\mathrm{a}, \mathrm{b}, *}$ and Graham Pawelec ${ }^{\mathrm{a}}$ \\ ${ }^{a}$ Tübingen Aging and Tumour Immunology Group, Center for Medical Research, University of Tübingen \\ Clinical School, Tübingen, Germany \\ ${ }^{\mathrm{b}}$ Department of Agriculture, Bacha Khan University, Charsadda, Khyber Pakhtunkhwa, Pakistan
}

Received 25 March 2012

Accepted 10 September 2012

\begin{abstract}
Demographic shifts worldwide are resulting in ever-increasing numbers of the elderly in both developed and developing countries. With aging come changes in physical and physiological integrity that are accompanied by a gradual decline in immunocompetence, commonly termed 'immunosenescence'. Indeed, there are marked differences between young and old subjects with respect to the proportions of naïve and memory $\mathrm{T}$ cells and less marked differences in $\mathrm{B}$ cells and other immune cells. The number and proportion of late-stage memory $\mathrm{T}$ and B cells commonly increases, being particularly prominent in the CD8+ cytotoxic T cell pool. The accumulation of late-stage potentially "terminally" differentiated CD8+CD27-CD28-CD45RA+ cells is often considered a hallmark of immunosenescence. Malnutrition in old age can further add to the severity of this age-associated remodeling of the immune system. Age-associated obesity, in particular, is accompanied by greater chronic inflammation, as reflected in increased plasma concentrations of C-reactive protein (CRP), IL-6, TNF and other factors which may mark compromised immunity. These physiological and immunological changes accompanying aging, markedly affected by nutritional status, are likely to be different in different parts of the globe. Data suggest a gradual decline in both nutritional status and immune functions with aging, but the details of these processes, and potential differences in different societies are unclear. In the following review, we will discuss the hallmarks of age-associated immune system changes and consider how these might be affected by nutritional status.
\end{abstract}

Keywords: Aging, physical changes, nutrition, immunity, immunosenescence

\section{List of Abbreviations}

$\begin{array}{ll}\text { APC } & \text { Antigen Presenting Cells } \\ \text { BMI } & \text { Body Mass Index } \\ \text { BMR } & \text { Basal Metabolic Rate } \\ \text { CM } & \text { Central Memory } \\ \text { CMV } & \text { Cytomegalovirus } \\ \text { CR } & \text { Caloric Restriction } \\ \text { CRP } & \text { C-reactive protein } \\ \text { DTH } & \text { Delayed-Type Hypersensitivity }\end{array}$

*Corresponding author: Iftikhar Alam, Department of Agriculture, Bacha Khan University, Charsadda, Khyber Pakhtunkhwa, Pakistan 25000. E-mails: iftikharalam@aup.edu.pk; iftikhar.alam@ awkum.edu.pk.

\section{EM Effector Memory}

GM-CSF Granulocyte colony-stimulating factor

IL-1RI Interleukin 1 receptor, type I

IL-6 Interleukin-6

LBM Lean Body Mass

IRP Immune Risk Profile

MCH Major Histocompatibility Complex

MH Metabolically Healthy

MUH Metabolically Unhealthy

NK Natural Killer

PCNA Proliferating Cell Nuclear Antigen

TLC Total Lymphocyte Count

TNF Tumor Necrosis Factor

WEIRD White, Educated, Industrialized, Rich and Democratic 


\section{Physical and physiological changes associated with the aging process}

Demographic studies have indicated that the numbers of elderly individuals in both developed and developing countries is increasing, due predominately to major improvements in living conditions and better health-care facilities [1-3]. Indeed, worldwide, life expectancy has increased markedly during the last few decades [1], promoted further by recent improvements in nutrition, hygiene, antimicrobial therapy and vaccinations $[4,5]$. A universal definition of "elderly" is hard to formulate, as it must rely on the conditions and circumstances that are different in different countries and societies. Nonetheless, most countries in the developed world have accepted the chronological age of 65 years as a definition of an "elderly" or "old" person [6], although it is noted that this cut-off derives from living conditions of over a century ago. Presently, a redefinition of elderly has been discussed in industrialized countries, where most studies indicate that a figure of $\geq 75$ years [7] may be more appropriate, whilst in developing countries, it may still be appropriate to consider "elderly" as 65 years of age. Throughout the current review we will use this arbitrary cut-off of 65 years.

Changes in the immune system with aging have been studied extensively over the past few decades, although most studies report differences between young and old in cross-sectional studies in developed countries and attribute changes to age. The conclusion from the majority of these studies is that aging leads to marked changes in the composition, function and competence of the human immune system, commonly termed 'immunosenescence' [8-10]. These changes in the immune system with age are in part thought to contribute to increased morbidity and mortality from infectious disease, e.g., respiratory tract pathogens $[11,12]$, gastrointestinal infections [13], and antigenspecific responses to orally administered vaccines are diminished [14]. Major age-related phenotypic and functional changes to the immune system manifest as significant alterations in the T-cell compartment of adaptive immunity [9], whilst smaller changes in Bcell function [15] and the innate immune system [16] are also apparent.

During normal aging, a decline in lean body mass (LBM) with a simultaneous increase in fat tissue usually occurs, leading to adverse changes in physiological functioning of the body due to large alterations in body composition. Increased fat infiltration into muscles with aging is associated with reduced muscle performance, a reduction in muscle strength, a sudden fall in basal metabolic rate (BMR) and a reduced ability to resist infections and a decline in immunity [17]. Changes in body weight are a sign of changes in LBM [18-21] and weight loss in the elderly is typically unintentional and is associated with increased risk of functional impairment [21], mortality [18, 22], and other related complications [23]. Perhaps rather surprisingly, the exact prevalence of weight loss among elderly adults is not well documented, and the literature on this topic is limited to a few small studies that utilize a variety of definitions for weight loss [24, 25]. For example, over a 3 year follow up, more than $15 \%$ of the Cardiovascular Health Study cohort experienced $\geq 5 \%$ weight loss while an additional $5 \%$ had weight loss of $\geq 10 \%$ [25]. In a separate study, one quarter of male Veterans living in Seattle experienced $\geq 4 \%$ weight loss over a 2 year period [26].

Gender differences in nutritional and health status of elderly have also been investigated extensively. Of particular note are studies reporting gender-associated differences in total body fat distribution and content; with women having higher levels of adiposity deposited in the subcutaneous compartment compared to men [27]. Particularly, after menopause the fat deposition in women shifts toward a more central/male-like pattern of fat distribution [28]. It has been previously shown that females between 12 and 80 years of age have a higher percentage of body fat as compared to males. This difference starts notably with puberty [29] and varies between $6-11 \%$ higher for every decade studied [30] with variations due to ethnicity, genetic, and environmental factors [31]. Sex hormones, including oestrogen, progesterone and androgen, have been reported primarily responsible for these differences [32-37]. Importantly, these sex differences in the distribution of BF are significantly associated with differential risks for various chronic and immune diseases [38].

With such marked physical and physiological changes with aging, the overall nutritional well-being of the individuals is compromised. Consequently a number of nutrient deficiencies emerge in old age including zinc [39], vitamins A, B6, folate and B12 $[40,41]$. Data from the third National Health and Nutrition Examination Survey [42] in the USA as well as other studies [43-46] clearly demonstrate a linear decline in food intake starting from the age 20 to 80 years in both men and women, particularly a drastic 
decrease in caloric intake [47]. Average daily energy intake has been reported to decreases by about $30 \%$ between 20 and 80 years [47]. The loss of muscle mass with aging can further contribute to a loss of mobility [48], and decreased physical functioning and activity, which may lead to reduced energy requirement [49]. It is also noteworthy that the rate of the aging process may differ greatly between individuals, resulting in different subgroups within the elderly population (e.g., the healthy elderly versus the frail older group) [50], implying that nutrient requirements with aging are highly individualized.

\section{Immunity and its modulation by age and diet}

\subsection{Composition of the immune system}

\subsubsection{Innate immunity}

Innate immunity is comprised of five types of defensive barriers: anatomic, physiologic, endocytic, phagocytic, and inflammatory. Soluble factors such as lysozyme, which is a hydrolytic enzyme capable of cleaving the bacterial cell wall, or complement, also contribute to innate immunity [51-54]. The innate immune system is also composed of protective cells and molecules. Some examples are natural killer cells (NK cells), scavenging macrophages $[52,53]$ and the complement system $[53,54]$.

\subsubsection{Adaptive immunity}

The other main arm of immunity is termed adaptive because it generates highly antigen-specific memory after encountering target antigens which, unlike those triggering the innate system, are infinitely variable, usually derived from infectious agents. Adaptive immune cells are the thymus-dependent $\mathrm{T}$ cells and the antibody-producing B cells, produced in the bone marrow by continuous haematopoiesis, a process requiring stem cell renewal over the whole lifespan, which may be affected by age and extrinsic circumstances $[51,52]$.

\subsection{Cells of the immune system}

\subsubsection{T and B cells}

Most of the lymphocytes in the blood are $\mathrm{T}$ cells, making up 22-30\% of total nucleated white cells (the majority of which are polymorphonuclear phagocytes, part of the innate immune system), whereas circulating
B cells represent only 7-10\% of white blood cells. T and $\mathrm{B}$ cell differentiation stages can be distinguished by their expression or lack of expression of certain cell surface molecules. For example, approximately $75 \%$ of circulating B cells in young people do not express a monomorphic costimulatory receptor called CD27, indicating that they have recently emerged from the bone marrow and have not yet encountered antigen in the periphery $[52,55]$.

While B cells mature in the bone marrow, $\mathrm{T}$ cell precursors migrate to and mature in a distinct organ, the thymus, where they go through further developmental stages, to produce mature naive CD4+ and CD8+ T cells (often called "helper" and "cytotoxic" $\mathrm{T}$ cells, respectively). CD4 and CD8 are cell surface co-receptors which assist in binding of the $\mathrm{T}$ cells to antigen-presenting cells (APC), required for their activation. After their "education" in the thymus, CD4+ $\mathrm{T}$ cells recognize peptide fragments of antigen only when presented in the context of class II self-major histocompatibility molecules (MHC class II) by the APC, usually dendritic cells (DC). In contrast, CD8+ T cells recognize shorter peptide fragments presented on MHC class I molecules. On completion of maturation, i.e. elimination of overtly self-reactive cells and selection of cells recognizing self-plus-antigen complexes, these preprogrammed naive cells leave the thymus and migrate to the periphery. Clearly, the output of naïve T cells depends on the integrity of the thymus, but this with changes adversely with age and poor nutrition. Näive T cells are long-lived cells and can circulate for years if not stimulated by their cognate antigen (processed and presented by APC, as mentioned above). They may, however, die before ultimately encountering their specific antigen, and this could happen in old age [56], leaving a "hole in the repertoire" should infection with the relevant specific pathogen occur in later life. Otherwise, upon antigen encounter, näive $\mathrm{T}$ cells become activated, proliferate and differentiate into memory and effector $\mathrm{T}$ cells to exert their antipathogen functions. CD8+ cytotoxic $\mathrm{T}$ cells mediate lytic reactivity once activated and can kill infected cells directly by production of cytotoxins such as perforins and granzymes [57]. Activated CD4+ T helper T cells supply cytokines to 'help' B cell maturation and CD8 differentiation, and may also be cytotoxic themselves.

\subsubsection{Sub-populations of $T$ cells}

CD4+ and CD8+ T cells are further divided and categorized into sub-populations based on the expression 
of additional cell surface molecules indicative of differentiation stage. This division is useful when one is interested in studying various cell phenotypes associated with specific functional characteristics. However, it must be borne in mind that these represent a continuum of differentiation stages and are not discrete cell subsets.

There are at least two established models in use for identification of $\mathrm{T}$ lymphocyte differentiation stages. The first model utilizes the expression of the TNF-family costimulatory receptor CD27 in combination with the CD45RA isoform of the leukocyte common antigen (a phosphatase). This strategy identifies one population of antigen-inexperienced cells, the naive cells (CD27+CD45RA+) and three memory populations designated central memory (CM; CD27+CD45RA-), effector memory (EM; CD27-CD45RA-), and the most differentiated 'revertant' memory cells, which have re-expressed the 'naïve' cell marker CD45RA (EMRA; CD27CD45RA+) [58-60].

In a second model, instead of CD27, the immunoglobulin super-family co-stimulatory molecule CD28 or the chemokine/lymphoid homing receptor CCR7 are used in combination with CD45RA $[59,61,62]$. Identifying cells on the basis of this model also gives three distinct subsets. These subsets also differ along a continuum of differentiation stage; early stage (CD27+CD28+), intermediate stage (CD27+CD28-), and late stage differentiated cells (CD27-CD28-) [61, 62]. Nevertheless, these models do not allow absolutely clear distinctions between naive and memory cells. The reason for this limitation is that due to overlapping dynamic loss and re-expression of CD27, CD28, and CD45RA with cellular differentiation and antigenic stimulation, several of the sub-populations described share similar functional characteristics. Thus, naïve, CM and early-stage differentiated cells show a propensity to migrate to the secondary lymphoid organs. There, the cells interact with APC and rapid proliferation occurs, which produces the required larger numbers of antigen-specific effector cells. These then readily migrate to inflamed tissues [59, 60]. CM cells, which have previously responded to infection, have relatively greater capability to produce effector cells more quickly than antigen-inexperienced naïve cells [59]. The EM and EMRA sub-populations strongly overlap with the intermediate and late-stage differentiated cells and they migrate to peripheral tissue (e.g. the skin, mucous membrane etc). In addition, they express cytotoxic effector molecules (e.g. perforin and granzyme $\mathrm{B}$ ) and readily produce inflammatory cytokines (e.g. IFN- $\gamma$ ) $[64,65]$, which can help in providing immunity to the body in a number of ways but may also inflict collateral damage if not closely controlled. The use of the terms naive, CM, EM and TEMRA nonetheless provide a useful conceptual framework in which to view ageand nutrition-associated changes to immune status.

\subsubsection{Homeostasis of T cells}

It has now been well established that the homeostasis of näive T-cells remains relatively stable during life [66]. Production of large numbers of näive $T$ cells in early life is followed by their exposure to pathogens, clonal expansion, and differentiation, performance of their function, clonal contraction and death of the majority with retention of some as memory cells. In later life, the numbers of naive $\mathrm{T}$ cells can only be increased by homeostatic proliferation of existing näive $\mathrm{T}$ cells in the periphery after ageassociated thymic involution [67]. A steady loss of näive $\mathrm{T}$ cells throughout life is therefore the norm, as they differentiate into memory/effector $\mathrm{T}$ cells after antigen challenge. Because thymic output declines significantly with age due to thymic involution [68], there is a decline in the contribution of the thymus to näive Tcell homeostasis over the life-span. This suggests that homeostasis of the näive T-cell compartment in adults may rely mostly on peripheral T-cell proliferation and prolonged survival (longevity) of näive $\mathrm{T}$ cells. This contributes to the age-related changes in the immune system, particularly in T cells, as discussed in detail in the next section.

\subsection{Aging and immunity}

Changes to the immune system with aging have been studied and reviewed extensively over the past few years $[9,11,69,70]$ as briefly summarized in Table 1 . However, most of the previous studies mainly reported on the so-called WEIRD (white, educated, industrialized, rich and democratic) aged populations in the developed world. Hence, much of our knowledge of immunity and aging is derived from and may in some ways be limited to this minority of people worldwide.

Although many studies refer to age-associated changes, the majority is cross-sectional and can therefore actually only refer to differences between a current 
Table 1

Selected Age-related changes in B and T cells and their activities

\begin{tabular}{ll}
\hline Decrease & Increase \\
\hline CD28 & KLRG1 \\
CD27 & ILT-2 (CD85 j) \\
CCR7 & CD57 \\
IL-2 production & CD49d \\
Delayed-type hypersensitivity & KIR-positive T cells \\
CD45+ T cells & CD244 \\
Thymic output & CD45RO+ T cells \\
B-cell-derived antibody affinity & Memory B cells \\
Lymphopoiesis (B and T cells) & CMV-specific CD8+ T cells \\
Naive B cells & CMV-specific CD4+ T cells \\
Generation of immature B cells & \\
\hline
\end{tabular}

Adapted from: Larbi A, Franceschi C, Mazzatti D, Solana R, Wikby A, Pawelec G (2008) Aging of the Immune System as a Prognostic Factor for Human Longevity. Physiology 23:64-74.

young and old cohort. It is usually difficult to investigate the actual changes in immunity with age in humans in longitudinal studies due to time and resource constraints [71]. However, there is limited number of longitudinal studies on individuals over 85 years of age, the group of people deliberately focused on in the Swedish OCTO/NONA studies. Both OCTO (subjects selected for exceptionally good health) and NONA (free-living subjects but representative health status) identified a so-called "immune risk profile (IRP)" for 2, 4 and 6-year mortality at follow-up consisting of an inverted CD4:CD8 ratio of $<1$, accumulations of CD28-negative CD8+ T cells, and decreased $\mathrm{B}$ cells [72]. However, nutritional variables were unfortunately not taken into account in these studies.

Marked differences have been observed between young and old subjects in the proportions of naive and memory $\mathrm{T}$ cells present in the peripheral blood. In newborns, the ratio of naive to memory $\mathrm{T}$ cells is quite high; in adults the ratio is reversed because most of the naive $\mathrm{T}$ cells have been exposed to antigen, and hence converted to memory cells, as mentioned above. As the thymus progressively involutes with age, fewer $\mathrm{T}$ cells are produced, and the naive $\mathrm{T}$ cell subpopulation is not replenished. Consequently, the stock of naïve $T$ cells becomes depleted and the aged immune system cannot respond as well as a young person to a new antigen [51]. It is important to note, however, that possessing fewer naive cells has not actually been shown to be deleterious in aged people. $\mathrm{T}$ cell homeostasis ensures that as naive cells are lost, there is a compensatory increase in the numbers of memory cells. Consequently, the number and proportion of memory $\mathrm{T}$ cells with a late-differentiated phenotype (e.g. CD27-CD28-CD45RA+) commonly increases [73-76]. These phenotypic changes are particularly prominent in the cytotoxic $\mathrm{T}$ cell pool.

The accumulation of CD8+CD27-CD28-CD45$\mathrm{RA}+$ cells is considered a hallmark of immunosenescence [73-75], which implies that young individuals exhibit marked alterations in their $\mathrm{T}$ cell repertoire as compared to the elderly $[77,78]$. As with the naive cell situation, however, this "remodeling" of immunity, or rather the relative proportions of $\mathrm{T}$ cell differentiation phenotypes, has never been shown to be causally related to mortality or any other deleterious clinical outcome, and should thus be considered a hallmark of aging but not necessarily "senescence" per se. It may be viewed as an adaptive change to the requirements of an elderly host, and has been termed "remodeling".

However, as discussed above, it is clear that the involution of the thymus is an important feature of normal anatomical as well as physiological development but nonetheless has profound effects on aging of the immune system [79-81]. Thus, even the apparently normal shrinkage of the thymus may have an active role as a weakening source of näive T lymphocytes and the related thymic hormones [82]. Consequently, this process indirectly results in immunity being greatly dependent on the existing pool of memory $\mathrm{T}$ cells and the remaining naïve cells depending on the individual's "immunological history" of exposures [83].

We now know that young adults thymectomised in the first few years of life exhibit reduced numbers and proportions of naive $\mathrm{T}$ lymphocytes, and sometimes increased numbers of cytotoxic $\mathrm{T}$ cells in adulthood [84-86]. These immune profiles of the young after thymectomy are quite similar to those of far older adults, who also show little or no thymic output $[84,85]$. The thymectomy study also highlighted an important contribution of the individual's exposure to micro-organisms in determining their immune profile. Sauce et al. showed that infection with Cytomegalovirus (CMV) exhibited more severe alterations in the $\mathrm{T}$ cell repertoire compared to those who were free of CMV infection [84]. This combination of little or no thymic output and selective expansion/maintenance of cytotoxic T cell populations leads to a gradual 'filling of the immunological space' with CD8+ T cells just as is the case with "normal" aging [87]. It is noteworthy that CMV infection was also part of the cluster of parameters making up the immune risk profile in the OCTO/NONA studies, and 
that in cross-sectional studies of CMV-negative people, no significant age-associated difference in proportions of naive $\mathrm{T}$ cells can be found [88].

Most immunosenescence research has focused on adaptive immunity as it was once postulated that innate immunity is better preserved with aging [89]. It is now appreciated, however, that age-related changes are visible in nearly all cells of the innate immune system as well. For example, aging is associated with decreased natural killer cell function and altered neutrophil migration $[90,91]$, which starts as early as adolescence [74, 92]. Immunosenescence, by definition, is reflective of the erosion occurring in immune competence over the course of life and is at its maximum in old age $[9,93,94]$.

\subsection{Nutrition and immunity in the elderly}

\subsubsection{Under-nutrition and its effects on the immune system}

On the other hand, undernutrition also exerts a strong negative effect on immune responses in the elderly [reviewed in ref. 95]. Early work on nutrition and immune functions was primarily based on the findings from studies on nutritional deficiencies in young children from developing countries [96]. Much evidence today points to nutrition as an important determinant of immune functions across all age groups worldwide. Cell-mediated immunity is particularly sensitive to deficiencies in macronutrients [reviewed in ref. 97]. In the elderly, immunological dysfunctions may occur because of single nutrient deficiencies, such as of vitamin A, iron or zinc, or because of multiple nutrient deficiencies in conjunction with general malnutrition [47, 98-114] and protein-energy malnutrition [115, 116], many of which can be reversed by nutritional supplementation interventions $[117,118]$.

Nutrient deficiencies often result in an increased risk of developing infections $[12,13,119,120]$. This relationship between nutrient deficiencies and infections has been better investigated in studies with the effect of multi-micronutrient supplementation on resistance to infection in the elderly subjects $[113,121]$. While some have shown benefits of nutritional intervention in reducing the burden of infectious diseases in the elderly [e.g. 121, 122], others have shown no significant effects [e.g. 112]. A multi-center nutritional trial [123] demonstrated a slightly reduced risk of pressure ulcer infections in elderly patients who were given daily protein-calorie supplements. The study concluded that this energy protein intervention was associated with a decreased risk of pressure ulcer incidence. The study of institutionalized elderly persons that demonstrated clinical benefits [122] also suggests that trace minerals, in particular, may be the key nutritional factors for preventing infection in older adults. Other studies of zinc supplementation in older adults have demonstrated enhanced DTH responses and elevated lymphocyte numbers and function of natural killer cells [e.g. 39]. Some studies have examined the effects of vitamin C (ascorbic acid) supplementation as adjunctive therapy for respiratory tract infections. One such study [116] recruited hospitalized elderly patients with bronchitis or pneumonia to compare vitamin C ( $200 \mathrm{mg} /$ day) with placebo. The addition of the deficient nutrients back to the diet can restore immune function and resistance to infection [117]. Taken altogether, states of malnutrition and infection can aggravate each other and lead to a vicious circle [100].

\subsubsection{Over-nutrition and its effects on the immune system}

Like undernutrition (or underweight), overweight and obesity are the other reciprocal forms of malnutrition at epidemic proportions globally [118]. The relationship between obesity and immunity is logically to be expected mainly on three lines of evidence. First, obesity is linked with a multiplied risk of virtually all types of cancers. Second, obesity has a close association with all chronic, systemic states of inflammation, which may contribute to the development of obesity-related co-morbidity. Third, a number of hormones (e.g. leptin and adiponectin), which have been shown to play an important role in regulating immune functions, are likely to be deregulated in obesity [124].

\subsubsection{Obesity as chronic inflammation}

Obesity in humans is associated with low-level inflammation [125]. The inflammatory response triggered by obesity involves a number of components of the classical inflammatory response to pathogens [126]. These include systemic increases in circulating inflammatory cytokines, adipokines and acute phase proteins, recruitment of leukocytes to inflamed tissues, activation of tissue leukocytes, and generation of reparative tissue responses. However, the nature of obesity-induced inflammation is unique in comparison to other inflammatory paradigms including infections, 
autoimmune diseases, and the likes. Qualitatively, for example, in chronic obesity, a low-grade activation of the innate immune system is produced that affects steady-state measures of metabolic homeostasis over time. Obesity-associated inflammation is hence characterized by a low-level but chronic inflammatory state.

The association between obesity and the development of major complications in acute pancreatitis [127], fatty liver diseases [128], vascular inflammation and coronary heart disease [129], chronic obstructive pulmonary disease [130], risk of cerebral ischemia and brain injury [131], atherosclerotic vascular disease and myocardial infarction [132], and cancers [133] are strongly linked to chronic inflammation. In particular, insulin resistance, a direct or indirect result of obesity, is characterized by a chronic state of subclinical inflammation [134] and inactivation of a number of inflammatory mediators [135]. An elevated serum concentration of CRP [136], IL-6, IL- 8 and TNF is observed in obese individuals with elevated insulin resistance [137]. In brief, obesity may affect immunity through the mediation of one or more of the aforementioned inflammatory states.

In addition to the findings that obesity leads to inflammation, there are also some recent data showing that the immune system can affect obesity in the same way as obesity can affect immunity. In particular, deficiency of several genes coding for innate immune factors (e.g., IL-6, GM-CSF, IL-1RI, and IL18 ) has been shown to lead to mature-onset obesity in mice [138, 139]. Moreover, combined IL-6 and IL-1 deficiency causes early-onset obesity in mice [139]. Conversely, mice with enhanced IL-1 activity are lean and resistant to diet-induced obesity [140]. IL-6 has been shown to have obesity suppressing effects by the virtue of its ability to increase energy expenditure in tissues [141]. Furthermore, it is believed that the hypothalamus might be the site of action in the brain since an altered expression of peptides responsible for regulation of energy balance has been found in IL-6-deficient mice. The mechanism whereby IL-1 mediates anti-obesity effects may be partly through leptin as it has been shown that leptin injection specifically increases the hypothalamic levels of IL-1 $[142,143]$.

\subsubsection{Caloric restriction (CR), inflammation and immunity}

The effects of obesity and its associated inflammation can be reversed through caloric restriction (CR); a state of chronic negative balance achieved in various experimental animals. CR has been successfully exploited for robust, nongenetic means of extending the mean and maximal lifespan in some experimental animals [144]. With a sufficiently large set of research data, mostly from studies with animal models, the CR has been suggested to have significant impact on various components of the immune system [145]. These include responses of T cells to mitogens, NK cell activity, CTL activity, and the ability of mononuclear cells to produce proinflammatory cytokines [145-147]. CR has been suggested to have positive effects on NK cells and CTL as reflected in the much reduced incidence of tumors in caloric restricted mice [148-150].

What is the possible mechanism by which CR may induce the aforementioned effects? An improvement in thymic cellularity has been suggested as a result of CR in old mice [150]. In that study the number of total thymocytes and double-positive $\mathrm{T}$ cells was doubled, interestingly, without significantly increasing the size of the thymus It was, therefore, suggested that CR preserves immature $\mathrm{T}$ cell precursors in the thymus during aging to maintain higher concentrations of circulating $\mathrm{T}$-helper and naive $\mathrm{T}$ cells in peripheral blood. Using aged rats, CR has been shown to attenuate the age-associated increase in memory:naive $\mathrm{T}$ cell ratios, attributable to a significant reduction in proinflammatory cytokines such as TNF and IL-6 [150]. A CR-associated increase in thymopoiesis and improvement in the TCR diversity with increased naive:memory $\mathrm{T}$ cell ratios in the periphery has also been demonstrated [151]. What is the underlying mechanism of CR-induced effects on the thymus? This remains unclear, but arguably, the neuroendocrine factors responsible for regulating energy balance in the body may be partly having significant effects on immune function during CR by causing an increase in a number of orexigenic factors, importantly, ghrelin [152] and possibly by reducing anorexigenic hormones, such as leptin [153].

\subsubsection{Metabolic implications of obesity}

It is noteworthy, however, that not all obese individuals may be similarly at risk for adverse inflammatory outcomes and immune compromise and that metabolically healthy $(\mathrm{MH})$ obese individuals have a considerable edge over metabolically unhealthy (MUH) obese individuals. As an example, Lynch et al. reported significantly more CD8+ and NK cells in lean controls compared to obese individuals. The authors 
further reported no differences in CD4+ T cell levels between obese and lean individuals [154]. In addition the authors observed that the phenotypes of immune cells were also different between obese and lean individuals with regard to activation and differentiation markers and that obese individuals had significantly less CD45RA+ cells. However, when obese individuals were further split into metabolically healthy $(\mathrm{MH})$ and unhealthy (MUH) groups, it was found that circulating NK cells and CD8+ cell levels were significantly reduced only in the UH obese group. There are other studies reporting large health differences between these two distinct groups [154-159]. It has been suggested that the unique metabolically healthy subgroup of obese individuals appear to be protected or more resistant to the development of co-morbidities associated with obesity. Despite having excessive body fat, these individuals display a favorable metabolic profile characterized by high levels of insulin sensitivity, no hypertension, normal lipid, inflammation, and hormonal profiles and importantly a favorable immune profile [159].

\subsubsection{Malnutrition and thymic involution}

Thymic involution in normal aging has been established for many years, but the idea that nutrition also plays a vital role predates this realization by a long time: in 1810, J.F. Menkel noted the relationship between the size and functions of the human thymus and malnutrition [16]. He described atrophy of the thymus in malnourished patients and since then, the term 'nutritional thymectomy' has been coined and is in common usage today. By 1845 , Simon had observed that the thymus is 'a barometer of malnutrition and a very sensitive one' [161]. Interestingly, these observations were made, however, over almost a century before the role of the thymus in lymphocyte development was truly understood. Currently, it is well-established that malnutrition directly leads to thymic involution, truly making the thymus 'a barometer of malnutrition and a very sensitive one' [161].

To link malnutrition with immune decline, it has been suggested that general undernutrition with specific deficiencies of some micronutrients (vitamin B6, amino acids, fatty acids, and zinc) results in decreased thymic weight with symptoms of immunosuppression [162-165]. A considerable amount of research work has been conducted in both humans and animals on the impact of protein-energy malnutrition [e.g. ref. 166], and on $\mathrm{Zn}$ [e.g. ref. 167] in relation to thymic development. Much of this work has used the simple outcome measure of thymic size, although some of the studies, particularly those on humans, have looked at cell-mediated immunity [168, 169].

On the other hand, nutritional deprivation has been shown to have proportionately greater impact on the size of thymus [170]. However, just as the size of thymus has been suggested as 'a crude index of function', $\mathrm{T}$ cell number and various tests of cell-mediated immunity are also 'crude measures of protection' [161]. Circulating T-cell levels are homeostatically regulated and hence often maintained or in most of the cases may be even elevated in sick and malnourished individuals, which may mask defective functions [168, 169] or a 'critical hole' in the T-cell repertoire caused by defective clonal selection in a malnourished thymus [161]. The observation that the thymus is always the organ most vulnerable to nutritional stress also fits with the observation that thymic atrophy represents an ordered process controlled by the induction of apoptosis [171].

Malnutrition-associated thymic atrophy has been reported to be largely due to changes in the lymphoid compartment. Thymocyte depletion appears as an outcome of both acute and chronic experimental protein malnutrition. The main phenotypic feature of this depletion is the loss of immature CD4+CD8+ cells, a finding consistently seen in malnutrition secondary to diets deficient in protein, metal elements (zinc, magnesium and iron) and vitamins [172-174]. As recently demonstrated in rats exposed to deficiencies of $\mathrm{Mg}$ or $\mathrm{Zn}$, the consequent thymocyte depletion actually reflects a massive apoptosis of these cells in the organ $[171,174]$. In addition to the increase in thymocyte death in the thymus of malnourished individuals, thymocyte proliferation seems to be affected. Thus, the numbers of thymic cells expressing the proliferating cell nuclear antigen (PCNA) marker decreases in malnourished rats [175]. This finding is further supported by data showing that thymocytes from animals subjected to distinct protocols of dietary restriction had low mitogeninduced proliferative responses [172]. Thus, the overall malnutrition-related thymocyte depletion seems to result from enhanced thymocyte death plus decreased thymocyte proliferation.

It would be important to know whether major changes in the thymic lymphoid compartment are also observed in humans suffering from malnutrition. Consistent with this, severe thymic atrophy with 
cortical thymocyte depletion is a common finding in necropsies of malnourished subjects [176]. In further support of this observation, thymic atrophy was also observed in malnourished children by the technique of echography [177]. Nevertheless, such alterations in the thymus seem to be reversible, at least in the experimental animals, if an appropriate diet is provided [178].

Like under-nutrition, over-nutrition which leads to obesity, has also been studied extensively with regard to thymic size and function. It has been suggested that obesity-induced accelerated thymic involution and restricted and limited $\mathrm{T}$ cell repertoire diversity represents a potent modifier of immunosenescence mechanisms that may further increase the risk and severity of infections in the 'gerobese' (geriatric obese) population [179]. This situation is likely to leave the subject with potentially greater predisposition to emerging diseases. Although the true mechanistic pathway of obesity-induced thymic involution is still not known, some previous studies examining immune function in extreme monogenic rodent models of obesity have shown clear thymic involution [180] and significant defects in T-cell responsiveness [181]. Interestingly, despite massive replacement of thymic with adipose tissue, the aging thymus still retains limited capacity for generating naive $\mathrm{T}$ cells [182], suggesting that restoration of thymic function may be achievable, particularly by the mechanisms of caloric restriction in obesity [151].

\section{Conclusions and outlook}

Decline in immunity with aging is well-established and much of the evidence today supports the notion of an overall impairment of immune functions even with normal "healthy" aging. There is also strong evidence that malnutrition (both under- and overnutrition) impairs elements of adaptive and innate immunity and that nutrition plays an important role in modulating immune functions. The relationship between malnutrition and infection is an intimate one, and it is often assumed that this is because of impaired immune function. There is good evidence of links, particularly between micronutrient deficiencies and immune impairment and obesity and a number of infections. Much of the evidence is suggestive that the size and function of the thymus is affected in the same way both by age and malnutrition; a fact further authen- ticating the importance of nutrition in the context of immune integrity.

Present day nutritional immunology research is mainly centered around studying the mechanisms underlying the modulation of immune responses by nutrients. Using many sophisticated tools, researchers of nutritional immunology try investigate the role of dietary components and their interactions with immunological parameters. The challenge remains to integrate nutritional immunity with age-associated changes to immune status, and to confirm that knowledge gained in one human population is comparable and informative for different populations. Further work is needed to elucidate the underlying mechanisms and how to perform adequate nutritional intervention for immunologic preservation. For this, larger studies on nutritional supplementation need to be launched and the observations of geriatricians integrated with nutritional immunology. There is still a need to study the effects of nutrients on different components of the immune system, because we know that immunity depends on multiple components that react differently to nutrients. Considering the complex nature of nutritional immunology, there is a need to dissect the networks of interactions that define the relationships between nutrition, immune function, infections and genetic background in age-associated changes of immune and inflammatory responses. Special emphasis must be given to find how to reverse and/or delay the onset of immunologic and age-related changes by appropriate dietary modifications and to determine the molecular mechanisms by which nutrients modulate immune cell functions. New methods have to be developed to use the immune response as a biologically meaningful index in determining specific dietary requirements.

The main focus of future nutritional immunology will include 1) studying cellular and molecular mechanisms of age and nutrition-induced changes in immune and inflammatory responses, 2) determination of the efficacy of food components (total calories, lipids, micronutrients such as vitamin E, zinc, flavonoids, and pre- and pro-biotics) on improving the immune function and/or dampening inflammatory responses using various techniques (cell culture, animal models and clinical trials), 3) determination of the efficacy of various food components in the prevention of infectious diseases in animal models, clinical trials and observational studies, 4) determination of the impact of reducing caloric intake on immune response of humans. 


\section{References}

[1] Christensen K, Doblhammer G, Rau R, Vaupel JW. Aging populations: The challenges ahead. Lancet. 2009;374:1196208.

[2] Gavazzi G, Hermann F, Krause KH. Aging and infectious diseases in the developing world. Clin Infect Dis. 2004;39: 83-91.

[3] Cho KH, Chung Y, Roh YK, Cho B, Kim CH, Lee HS. Health care for older persons: A country profile Korea. J Am Geriatr Soc. 2004;52:1199-204.

[4] Pawelec G, Derhovanessian E, Larbi A, Strindhall J, Wikby A. Cytomegalovirus and human immunosenescence. Rev Med Virol. 2009;19:47-56.

[5] World Health Organization. The European Health Report. WHO Regional Publications, European Series No. 97. Geneva, Switzerland: World Health Organization. 2002.

[6] Gorman M. Development and rights of the older people. Randel J, Germen T, Ewing D, eds. The Aging and Development Report: Poverty, Independence and the World's Older People. London: Earthscan Publications. 1999;3-21.

[7] Orimo H. Reviewing the definition of elderly. Nihon Ronen IgakkaiZasshi. 2006;43(1):27-34.

[8] Larbi A, Franceschi C, Mazzatti D, Solana R, Wikby A, Pawelec G. Aging of the immune system as a prognostic factor for human longevity. Physiology (Bethesda). 2008;23:64-74.

[9] Aw D, Silva AB, Palmer DB. Immunosenescence: Emerging challenges for an aging population. Immunol. 2007;120: 435-46.

[10] Pawelec G. When T Cells Get Old. Sci Aging Knowl Environ. 2005;50:39.

[11] Jartti L, Langen H, Söderlund-Venermo M, Vuorinen T, Ruuskanen O, Jartti T. New respiratory viruses and the elderly. Open Respir Med J. 2011;5:61-9.

[12] Crossley KB, Peterson PK. Infections in the elderly. Clin Infect Dis. 1996;22:209-15.

[13] Grubeck-Loebenstein B, Della Bella S, Iorio AM, Michel JP, Pawelec G, Solana R. Immunosenescence and vaccine failure in the elderly. Aging Clin Exp Res. 2009;21(3):201-9.

[14] Hagiwara Y, McGhee JR, Fujihashi K. Protective mucosal immunity in aging is associated with functional CD4+ T cells in nasopharyngeal-associated lymphoreticular tissue. J Immunol. 2003;170:1754-62.

[15] Frasca D, Diaz A, Romero M, Landin AM, Blomberg BB. Age effects on B cells and humoral immunity in humans. Aging Res Rev. 2011;10(3):330-35.

[16] Solana R, Pawelec G, Tarazona R. Aging and innate immunity. Immunity. 2006;24:491-94

[17] Greenlund LJS, Nair KS. Sarcopenia: Consequences, mechanisms and potential therapies. Mech Aging Dev. 2003; 124:287-99.

[18] Hughes VA, Frontera WR, Roubenoff R, Evans WJ, Fiatarone Singh MA. Longitudinal changes in body composition in older men and women: Role of body weight change and physical activity. Am J Clin Nutr. 2002;7:473-81.

[19] Song MY, Ruts E, Kim J, Janumala I, Heymsfield S, Gallagher D. Sarcopenia and increased adipose tissue infiltration of muscle in elderly African American women. Am J ClinNutr. 2004;79(5):874-80.
[20] Davison KK, Ford ES, Cogswell ME, Dietz WH. Percentage of body fat and body mass index are associated with mobility limitations in people aged 70 and older from NHANES III. J Am Geriatr Soc. 2002;50:1802-9.

[21] Alley DE, Ferrucci L, Barbagallo M, Studenski SA, Harris TBA. Research agenda: The changing relationship between body weight and health in aging. J Gerontol A BiolSci Med Sci. 2008;63(11):1257-9.

[22] Boyko EJ, Ahroni JH, Stensel V, Forsberg RC, Davignon DR, Smith DG. A prospective study of risk factors for diabetic foot ulcer: The Seattle diabetic foot study. Diabetes Care. 1999;22:1036-42.

[23] Shatenstein B, Ferland G. Absence of nutritional or clinical consequences of decentralized bulk food portioning in elderly nursing home residents with dementia in Montreal. J Am Diet Assoc. 2000;100(11):1354-60.

[24] Aloia JF, Vaswani A, Ma R, Flaster E. Aging in women-the four-compartment model of body composition. Metabolism. 1996;45:43-48.

[25] Newman AB, Lee JS, Visser M. Weight change and the conservation of lean mass in old age: The health aging and body composition study. Am J Clin Nutr. 2005;82:872-78.

[26] Wallace JI, Schwartz RS, Lacroix AZ, Uhlmann RF, Pearlman A. Involuntary weight loss in older outpatients: Incidence and clinical significance. J Am Geriatr Soc. 1995; 43:329-37.

[27] Clegg DJ, Brown LM, Woods SC, Benoit SC. Gonadal hormones determine sensitivity to central leptin and insulin. Diabetes. 2006;5:978-87.

[28] Lovejoy JC, Sainsbury A. Sex differences in obesity and the regulation of energy homeostasis. Obes Rev. 2009;10: 154-67.

[29] O'Sullivan AJ. Does oestrogen allow women to store fat more efficiently? A biological advantage for fertility and gestation. Obesity Reviews. 2009;10(2):168-77.

[30] Wells JC. Sexual dimorphism of body composition. Best Prac Res Clin Endo and Met. 2007;21(3):415-30.

[31] Mayes JS, Watson GH. Direct effects of sex steroid hormones on adipose tissues and obesity. Obesity Reviews. 2004;5(4):197-216

[32] Bjorntorp P. Hormonal control of regional fat distribution. Human Reproduction. 1997;12:21-25.

[33] Wilson JD, Foster DW. Eds., William's Textbook of Endocrinology, Saunders, Philadelphia, PA, USA, 8th edition. 1992.

[34] Spaaij CJ, van Raaij JM, Van der Heijden LJ, Schouten FJ, Drijvers JJ, De Groot LC, Boekholt HA, Hautvast JG. No substantial reduction of the thermic effect of a meal during pregnancy in well-nourished Dutch women. Br J Nutr. 1994;71(3):335-44

[35] Troisi RJ, Wolf AM, Mason JE, Klingler KM, Colditz GA. Relation of body fat distribution to reproductive factors in pre- and postmenopausal women. Obesity Research. 1995;3(2):143-51.

[36] Fruhbeck J, Jebb SA, Prentice AM. Leptin: Physiology and pathophysiology. Clin Phys. 1998;18(5):399-419.

[37] Wingard DL. Sex differences and coronary heart disease. A case of comparing apples and pears? Circulation. 1990;81:1710-12. 
[38] Shames RS. Gender differences in the development and function of the immune system. J Adol Health. 2002;30(4, Supplement 1):59-70.

[39] Prasad AS, Fitzgerald JT, Hess JW, Kaplan J, Pelen F, Dardenne M. Zinc deficiency in elderly patients. Nutrition. 1993;9:218-24.

[40] Tucker K. Micronutrient status and aging. Nutr Rev. 2005;53:S9-S15.

[41] Lesourd B, Mazari L. Nutrition and immunity in the elderly. Proc Nutr Soc 1999;58:685-95.

[42] Third National Health and Nutrition Examination Survey(NHANES III 1988-94). Reference Manuals and Reports [CD-ROM]. Bethesda, MD: National Center for Health Statistics. 1996.

[43] Rolls BJ, McDermott TM. Effect of age on sensory-specific satiety. Am J Clin Nutr. 1991;54:99.

[44] Subar AF, Harlan LC, Mattson ME. Food and nutrient intake differences between smokers and nonsmokers in the US. Am J Pub Health. 1990;80:1323-29.

[45] Wurtman JJ, Leiberman H, Tsay R, Nader T, Chew B. Calorie and nutrient intakes of elderly and young subjects measured under identical conditions. J Gerontol. 1988;43:174.

[46] Rolls BJ, Dimeo KA, Shide DJ. Age-related impairments in the regulation of food intake. Am J Clin Nutr. 1995;62: 923-31.

[47] Chapman IM. Nutritional disorders in the elderly. Med Clin North Am. 2006;90(5):887-907.

[48] Kent-Braun JA, Ng AV, Young K. Skeletal muscle contractile and non-contractile components in young and older women and men. J Appl Physiol. 2000;88:662-8.

[49] Gariballa S, Sinclair A. Aging and older people. In: Geissler CA. Powers HJ. Human Nutrition. Eleventh Edition. Elsevier Churchill Livingstone London. 2005;319-34.

[50] Hilmer SN, McLachlan AJ, Le Couteur DG. Clinical pharmacology in the geriatric patient. Fund \& Clin Pharm. 2007;21:217-30

[51] Alberts B, Alexander J, Julian L, Martin R, Keith R, Peter W. Molecular Biology of the Cell; 4th Edition. New York and London. Garland Science. 2002;pp. 1367.

[52] Kuby J. Immunology. 3rd Ed; WH Freeman and Company New York NY. 1997.

[53] Agerberth B, Gudmundsson GH. Host antimicrobial defense peptides in human disease. Current Topics in Microbiology and Immunology. 2006;306:67-90.

[54] Salzet M, Tasiemski A, Cooper E. Innate immunity in lophotrochozoans: The annelids. Current Pharmaceutical Design. 2006;12(24):3043-50.

[55] Schmidlin H, Diehl SA, Blom B. New insights into the regulation of human B-cell differentiation. Trends Immunol. 2009;30:277-85.

[56] Comans-Bitter WM, de Groot R, van den Beemd R, Neijens HJ, Hop WC, Groeneveld K, Hooijkaas H, van Dongen JJ. Immunophenotyping of blood lymphocytes in childhood. Reference values for lymphocyte subpopulations. J Pediatr. 1997;3:388-93.

[57] Toda H, Araki K, Moritomo T, Nakanishi T. Perforindependent cytotoxic mechanism in killing by CD8 positive $\mathrm{T}$ cells in ginbunacrucian carp, Carassiusauratuslangsdorfii. Dev Comp Immunol. 2011;35(1):88-93.
[58] Hamann D, Baars PA, Rep MH, Hooibrink B, Kerkhof-Garde SR, Klein MR, van Lier RA. Phenotypic and functional separation of memory and effector human CD8+ T cells. Journal of Exp Med. 1997;186:1407-18.

[59] Sallusto F, Geginat J, Lanzavecchia A. Central memory and effector memory $\mathrm{T}$ cell subsets: Function generation and maintenance. Ann Rev Immunol. 2004;22:745-63.

[60] Sallusto F, Lenig D, Forster R, Lipp M, Lanzavecchia A. Two subsets of memory T lymphocytes with distinct homing potentials and effector functions. Nature. 1999;401(6754): 708-12.

[61] Appay V, van Lier RA, Sallusto F, Roederer M. Phenotype and function of human T lymphocyte subsets: Consensus and issues. Cytometry A. 2008;73(11):975-83.

[62] van Lier RA, ten Berge IJ, Gamadia LE. Human CD8+ Tcell differentiation in response to viruses. Nat Rev Immunol. 2003;3(12):931-39.

[63] Appay V, Dunbar PR, Callan M, Klenerman P, Gillespie GM, Papagno L, Ogg GS, King A, Lechner F, Spina CA, Little S, Havlir DV, Richman DD, Gruener N, Pape G, Waters A, Easterbrook P, Salio M, Cerundolo V, McMichael AJ, Rowland-Jones SL. Memory CD8+ T cells vary in differentiation phenotype in different persistent virus infections. Nat Med. 2002;8:379.

[64] Lanzavecchia A, Sallusto F. Understanding the generation and function of memory $\mathrm{T}$ cell subsets. Curr Opin Immunol. 2005;17(3):326-32.

[65] Takahashi K, Mizuarai S, Araki H, Mashiko S, Ishihara A, Kanatani A, Itadani H, Kotani H. Adiposity elevates plasma MCP-1 levels leading to the increased CD11bpositive monocytes in mice. Journal of Biological Chemistry. 2003;278:46654-60.

[66] Hazenberg M, Galkina S, Chkhenkeli G, Stoddart C, McCune M. Presented Program Abstr Conf Retrovir Oppor Infect 11th 2004, San Franc Calif. 2004;11:8-11.(abstract no. 444).

[67] Sakaguchi S. Naturally arising CD4 + regulatory T cells for immunological self-tolerance and negative control of immune responses. Ann Rev Immunol. 2004;22:531.

[68] Cuss AK, Avery DT, Cannons JL, Yu LJ, Nichols KE, Shaw PJ, Tangye SG. Expansion of functionally immature transitional B cells is associated with human-immunodeficient states characterized by impaired humoral immunity. J Immunol. 2006;3:1506-16.

[69] Pawelec G, Barnett Y, Forsey R, et al., T cells and aging January 2002 update. Front Biosci. 2002;17:d1056d183.

[70] Pawelec G, Remarque E, Barnett Y, Solana R. T cells and aging. Front Biosci. 1998;15(3):d59-d99.

[71] Pawelec G, Akbar A, Caruso C, Effros R, GrubeckLoebenstein B, Wikby A. Is immunosenescence infectious? Trends Immunol. 2004;25:406-10.

[72] Pawelec G, Ferguson FG, Wikby A: The SENIEUR protocol after 16 years. Mech Aging Dev. 2001;122:132-4.

[73] Pawelec G. Immunity and aging in man. Exp Gerontol. 2006;41(12):1239-42.

[74] Akbar AN, Fletcher JM. Memory T cell homeostasis and senescence during aging. Curr Opin Immunol. 2005;17(5):480-5. 
[75] Bosch JA, Fischer JE, Fischer JC. Psychologically adverse work conditions are associated with $\mathrm{CD} 8+\mathrm{T}$ cell differentiation indicative of immunosenescence. Brain Behav Immun. 2009;23(4):527-34.

[76] Hadrup SR, Strindhall J, Kollgaard T, Seremet T, Johansson B, Pawelec G, Straten P, Wikby A. Longitudinal studies of clonally expanded CD8 T cells reveal a repertoire shrinkage predicting mortality and an increased number of dysfunctional cytomegalovirus-specific T cells in the very elderly. J Immunol. 2006;176(4):2645-53.

[77] Chidrawar S, Khan N, Wei W, McLarnon A, Smith N, Nayak L, Moss P. Cytomegalovirus-seropositivity has a profound influence on the magnitude of major lymphoid subsets within healthy individuals. Clin Exp Immunol. 2009;155(3): 423-32.

[78] Weinberger B, Lazuardi L, Weiskirchner I, Keller M, Neuner C, Fischer KH, Neuman B, Wurzner R, Grubeck-Loebenstein B. Healthy aging and latent infection with CMV lead to distinct changes in $\mathrm{CD} 8(+)$ and CD4(+) T-cell subsets in the elderly. Hum Immunol. 2007;68(2):86-90.

[79] Utsuyama M, Kasai M, Kurashima C, Hirokawa K. Age influence on the thymic capacity to promote differentiation of $\mathrm{T}$ cells: Induction of different composition of $\mathrm{T}$ cell subsets by aging thymus. Mech Aging Dev. 1991;58:267-77.

[80] Consolini R, Legitimo A, Calleri A. Distribution of agerelated thymulintitres in normal subjects through the course of life. Clin Exp Immunol. 2000;121:444-47.

[81] Douek DC, Koup RA. Evidence for thymic function in the elderly. Vaccine. 2000;18:1638-41.

[82] Zhang L, Lewin SR, Markowitz M, Lin HH, Skulsky E, Karanicolas R, He Y, Jin X, Tuttleton S, Vesanen M, Spiegel H, Kost R, van Lunzen J, Stellbrink HJ, Wolinsky S, Borkowsky W, Palumbo P, Kostrikis LG, Ho DD. Measuring recent thymic emigrants in blood of normal and HIV-1-infected individuals before and after effective therapy. J Exp Med. 1999;190:725-32.

[83] Woodland DL, Blackman MA. Immunity and age: Living in the past? Trends Immunol. 2006;27(7):303-7.

[84] Sauce D, Larsen M, Fastenackels S, Duperrier A, Keller M, Grubeck-Loebenstein B, Ferrand C, Debre P, Sidi D, Appay V. Evidence of premature immune aging in patients thymectomized during early childhood. J Clin Invest. 2009;119(10):3070-8

[85] Torfadottir H, Freysdottir J, Skaftadottir I, Haraldsson A, Sigfusson G, Ogmundsdottir HM. Evidence for extrathymic $\mathrm{T}$ cell maturation after thymectomy in infancy. Clin Exp Immunol. 2006;145(3):407-12.

[86] Eysteinsdottir JH, Freysdottir J, Haraldsson A, Stefansdottir J, Skaftadottir I, Helgason H, Ogmundsdottir HM. The influence of partial or total thymectomy during open heart surgery in infants on the immune function later in life. Clin Exp Immunol. 2004;136(2):349-55.

[87] Brunner S, Herndler-Brandstetter D, Weinberger B, GrubeckLoebenstein B. Persistent viral infections and immune aging. Aging Res Rev. 2001;10(3):362-9.

[88] Derhovanessian E, Maier AB, Beck R, Jahn G, Hähnel K, Slagboom PE, de Craen AJ, Westendorp RG, Pawelec G. Hallmark features of immunosenescence are absent in familial longevity. J Immunol. 2010;185(8):4618-24.
[89] Franceschi C, Bonafe M, Valensin S, Olivieri F, De Luca M, Ottaviani E, De Benedictis G. Inflamm-aging. An evolutionary perspective on immunosenescence. Ann NY Acad Sci. 2000;90:244-54.

[90] Panda A, Arjona A, Sapey E, Bai F, Fikrig E, Montgomery RR, Lord JM, Shaw AC. Human innate immunosenescence: Causes and consequences for immunity in old age. Trends Immunol. 2009;30(7):325-33.

[91] Gomez CR, Nomellini V, Faunce DE, Kovacs EJ. Innate immunity and aging. Exp Gerontol. 2008;43(8):718-28.

[92] Nikolich-Zugich J. Aging and life-long maintenance of Tcell subsets in the face of latent persistent infections. Nat Rev Immunol. 2008;8(7):512-22.

[93] Ostan R, Bucci L, Capri M, Salvioli S, Scurti M, Pini E, Monti D, Franceschi C. Immunosenescence and immune-genetics of human longevity. Neuro-immuno modulation. 2008;15(46):224-40.

[94] Pawelec G, Larbi A. Immunity and aging in man: Annual Review 2006/2007. Exp Gerontol. 2008;43(1):34-38.

[95] Han TS, Tajar A, Lean MEJ. Obesity and weight management in the elderly. Brit Med Bull. 2011;97:169-96.

[96] Chandra S, Chandra RK. Nutrition immune response and outcome. Prog Food Nutr Sci. 1986;10(1-2):1-65.

[97] Ames BN. Low micronutrient intake may accelerate the degenerative diseases of aging through allocation of scarce micronutrients by triage. Proc Nat Acad Sci USA. 2006;103(47):17589-94.

[98] Harbige LS, Gershwin ME. Antioxidant Nutrition and Immunity. In: Handbook of Nutrition and Immunity. Edit: Gershwin ME Nestel P Keen CL. Humana Press Totowa New Jersey. 2004;187-222.

[99] Beisel WR, Edelman R, Nauss K, Suskind RM. Singlenutrient effects on immunologic functions. Report of a workshop sponsored by the Department of Food and Nutrition and its nutrition advisory group of the American Medical Association. JAMA. 1981;245:53-8.

[100] Katona P, Katona-Apte J. The interaction between nutrition and infection. Clin Infect Dis. 2008;46(10):1582-8.

[101] Ahluwalia N, Mastro AM, Ball R, Miles MP, Rajendra R, Handte G. Cytokine production by stimulated mononuclear cells did not change with aging in apparently healthy wellnourished women. Mech Aging Dev. 2001;122:1269-79.

[102] Ryan AS, Craig LD, Finn SC. Nutrient intakes and dietary patterns of older Americans: A national study. J Gerontol. 1992;47:M145-M50.

[103] Lunn PG. Nutrition, immunity and infection. In The Decline of Mortality in Europe, ed. R Schofield, DS Reher, ABideau, New York: Oxford Univ., Press. 1991:pp. 131-45.

[104] Daly JM, Reynolds J, Sigal RK, Shou J, Liberman MD. Effect of dietary protein and amino acids on immune function. Critical Care Medicine. 1990;18(suppl.2):S86-S93.

[105] Gleeson M, Nieman DC, Pedersen BK. Exercise, nutrition and immune function. J Sports Sci. 2004;22:115-25.

[106] Lesourd BM, Mazari L. Nutrition and immunity in the elderly. ProcNutrSoc. 1999;58:685-95.

[107] Lesourd BM, Mazarin L, Ferry M. The role of nutrition in immunity in the aged. NutrRev. 1998;56:S113-S25.

[108] Meydani SN, Meydani M, Blumberg JB, Lekal S, Siber G, Loszewski R, Thompson C, et al., Vitamin E supplementation 
and in vivo immune responses in healthy elderly individuals. JAMA. 1997;277:1380-86.

[109] Gershwin ME, Nestel P, Keen CL. Handbook of Nutrition and Immunity. Humana Press Totowa New Jersy. 2004.

[110] Meydani SN, Leka LS, Fine BC, Dallal GE, Keusch GT, Singh MF, Hamer DH. Vitamin E and respiratory tract infections in elderly nursing home residents: A randomized controlled trial. J Am Med Assoc. 2004;292:828-36.

[111] Graat JM, Schouten EG, Kok FJ. Effect of daily vitamin E and multivitamin/multi-mineral supplementation on acute respiratory tract infections in elderly persons. J Am Med Assoc. 2002;288:715-21.

[112] Chavance M, Herbeth B, Lemoine A, Zhu BP. Does multivitamin supplementation prevent infections in healthy elderly subjects? A controlled trial. Int J Vitam Nutr Res. 1993;63:116.

[113] Girodon F, Galan P, Monget al, et al., Impact of trace elements and vitamin supplementation on immunity and infections in institutionalized elderly patients: A randomized controlled trial. MIN. VIT. AOX. Geriatric network. Arch Intern Med. 1999;159:748-54.

[114] Meydani SN, Santos MS. Aging: Nutrition and immunity. In: Gershwin ME German JB Keen CL eds. Nutrition and Immunology: Principles and Practice. Totowa NJ: Humana Press. 2000:403-21.

[115] Alam I, Larbi A, Pawelec G, Paracha PI. Relationship between anthropometric variables and nutrient intake in apparently healthy male elderly individuals: A study from Pakistan. Nutr J. 2011;10:111

[116] Hunt C, Chakravorty NK, Annan G, Habibzadeh N, Schorah CJ. The clinical effects of vitamin $\mathrm{C}$ supplementation in elderly hospitalised patients with acute respiratory infections. Int J Vitam Nutr Res. 1994;64:212-9.

[117] Calder PC, Kew S. The immune system: A target for functional foods? Br J Nutr. 2002;88:S165-S77.

[118] Ogden C, Carroll M, Curtin L, McDowell M, Tabak C, Flegal K. Prevalence of overweight and obesity in the United States, 1999-2004. J Am Med Assoc. 2006;295:13.

[119] Fraker P. Impact of Nutritional Status on Immune Integrity. In: Nutrition and Immunology. Principles and Practice by Gershwin ME, German JB, Keen CL. Humana Press. 2000:147-56

[120] Selmi C, Invernizzi P, Zuin M, Ansari Aa, Gershwin Me. Evaluation of the Immune Function in the Nutritionally AtRisk Patient. Inc: Handbook of Nutrition and Immunity. Edit: Gershwin ME, Nestel P, Keen CL. Handbook of nutrition and immunity. 2004;pp. 1-18.

[121] Schmoranzer F, Fuchs N, Markolin G, Carlin E, Sakr L, Sommeregger U. Influence of a complex micronutrient supplement on the immune status of elderly individuals. Int $\mathbf{J}$ Vitam Nutr Res. 2009;79(5-6):308-18.

[122] Girodon F, Lombard M, Galan P, Brunet-Lecomte P, Monget AL, Arnaud J, Preziosi P, Hercberg S. Effect of micronutrient supplementation on infection in institutionalized elderly subjects: A controlled trial. Ann Nutr Metab. 1997;41:98-107.

[123] Bourdel-Marchasson I, Barateau M, Rondeau V, DequaeMerchadou L, Salles-Montaudon N, Emeriau JP, Manciet G, Dartigues JF. A multi-center trial of the effects of oral nutritional supplementation in critically ill older inpatients. GAGE
Group. Groupe Aquitain Geriatriqued 'Evaluation Nutrition. 2000;16:1-5.

[124] Faggioni R, Jones-Carson J, Reed DA, Dinarello CA, Feingold KR, Grunfeld C, Fantuzzi G. Leptin-deficient $(\mathrm{ob} / \mathrm{ob})$ mice are protected from $\mathrm{T}$ cell-mediated hepato-toxicity: Role of tumor necrosis factor - and IL-18. PNAS. 2000; 97:2367-72.

[125] Clement K, Langin D. Regulation of inflammation-related genes in human adipose tissue. J In Med. 2007;262(4):42230.

[126] Hotamisligil GS. Inflammation and metabolic disorders. Nature. 2006;444:860-67.

[127] Evans AC, Papachristou GI, Whitcomb DC. Obesity and the risk of severe acute pancreatitis. Minerva Gastroenterol. Dietol. 2010;56:169-79.

[128] Tilg $\mathrm{H}$. The role of cytokines in non-alcoholic fatty liver disease. Dig Dis. 2010;28:179-85.

[129] Gomes F, Telo DF, Souza HP, Nicolau JC, Halpern A, Serrano CV Jr. Obesity and coronary artery disease: Role of vascular inflammation. Arq Bras Cardiol. 2010;94:255-60.

[130] Tkacova R. Systemic inflammation in chronic obstructive pulmonary disease: May adipose tissue play a role? Review of the literature and future perspectives. Mediators Inflamm. 2010;58:5989.

[131] Denes A, Thornton P, Rothwell NJ, Allan SM. Inflammation and brain injury: Acute cerebral ischaemia, peripheral and central inflammation. Brain Behav Immun. 2010;24:708-23.

[132] Ohman MK, Wright AP, Wickenheiser KJ, Luo W, Eitzman DT. Visceral adipose tissue and atherosclerosis. Curr Vasc Pharmacol. 2009;7:169-79.

[133] Wolin KY, Carson K, Colditz, GA. Obesity and cancer. Oncologist. 2010;15:556-65.

[134] Bastard JP, Maachi M, Lagathu C, Kim MJ, Caron M. Recent advances in the relationship between obesity, inflammation, and insulin resistance. Eur Cytokine Netw. 2006;17:4-12.

[135] Arkan MC, Hevener AL, Greten FR, Maeda S, Li ZW, Long JM, Wynshaw-Boris A, Poli G, Olefsky J, Karin M. IKK-beta links inflammation to obesity-induced insulin resistance. Nat Med. 2005;11:191-8.

[136] Shoelson SE, Lee J, Goldfine AB. Inflammation and insulin resistance. J Clin Invest. 2006;116:1793-801.

[137] Kahn SE, Zinman B, Haffner SM, O'Neill MC. Obesity is a major determinant of the association of C-reactive protein levels and the metabolic syndrome in type 2 diabetes. Diabetes. 2006;55:2357-64.

[138] Wallenius V, Wallenius K, Ahren B, Rudling M, Carlsten H, Dickson SL, Ohlsson C, Jansson JO. Interleukin-6-deficient mice develop mature-onset obesity. Nat Med. 2002;8:75-9.

[139] Chida D, Osaka T, Hashimoto O, Iwakura Y. Combined interleukin-6 and interleukin-1deficiency causes obesity in young mice. Diabetes. 2006;55:971-7.

[140] Matsuki T, Horai R, Sudo K, Iwakura Y. IL-1 plays an important role in lipid metabolism by regulating insulin levels under physiological conditions. J Exp Med. 2003;198:877-88.

[141] Wernstedt I, Edgley A, Berndtsson A, Fäldt J, Bergström G, Wallenius V, Jansson JO. Reduced stress- and cold-induced increase in energy expenditure in interleukin6-deficient mice. Am J PhysiolRegulIntegr Comp Physiol. 2006;291(3):R551-R7. 
[142] Garcia MC, Wernstedt I, Berndtsson A, Enge M, Bell M, Hultgren O, Horn M, Ahren B, Enerback S, Ohlsson C, Wallenius V, Jansson JO. Mature-onset obesity in interleukin-1 receptor I knockout mice. Diabetes. 2006;55:1205-13.

[143] Benrick A, Schéle E, Pinnock SB, Wernstedt-Asterholm I, Dickson SL, Karlsson-Lindahl L, Jansson JO. Interleukin-6 Gene Knockout Influences Energy Balance Regulating Peptides in the Hypothalamic Paraventricular and Supraoptic Nuclei. Journal of Neuro-endocrinology. 2009;21:620-8.

[144] Nikolich-Zugich J, Messaoudi I. Mice and flies and monkeys too: Caloric restriction rejuvenates the aging immune system of nonhuman primates. Exp. Gerontol. 2005;40:884-93.

[145] Spaulding CC, Walford RL, Effros RB. Calorie restriction inhibits the age-related dysregulation of the cytokines TNF- and IL-6 in C3B10RF1 mice. Mech. Ageing Dev. 1997;93:87-94.

[146] Spaulding CC, Walford RL, Effros RB. The accumulation of non-replicative, non-functional, senescent $\mathrm{T}$ cells with age is avoided in calorically restricted mice by an enhancement of T cell apoptosis. Mech Ageing Dev. 1997;93:25-33.

[147] Weindruch RH, Makinodan T. Dietary restriction and its effect on immunity and aging. Prog Clin Biol Res. 1981;67:319-25.

[148] Weindruch R, Walford RL. Dietary restriction in mice beginning at 1 year of age: Effect on life-span and spontaneous cancer incidence. Science. 1982;215:1415-8.

[149] Weindruch R. Effect of caloric restriction on age-associated cancers. Exp Gerontol. 1992;27:575-81.

[150] Jolly CA. Dietary restriction and immune function. J Nutr. 2004;134:1853-56.

[151] Messaoudi I, Warner J, Fischer M, Park B, Hill B, Mattison J, Lane M A, Roth G S, Ingram D K, Picker L J, Douek D C, Mori M, Nikolich-Zugich J. Delay of T cell senescence by caloric restriction in aged long-lived nonhuman primates. Proc Natl Acad Sci USA. 2006;103:19448-53.

[152] Yang H, Youm YH, Nakata C, Dixit VD. Chronic caloric restriction induces for estomach hypertrophy with enhanced ghrelin levels during aging. Peptides. 2007;28:1931-6.

[153] Shimokawa I, Higami Y. Leptin signaling and aging: Insight from caloric restriction. Mech Ageing Dev. 2001;122:1511-9.

[154] Lynch LA, O'Connell JM, Kwasnik AK, Cawood TJ, O'Farrelly C, O'Shea DB. Are natural killer cells protecting the metabolically healthy obese patient? Obesity. 2009; $17: 601-5$

[155] Brochu M, Tchernof A, Dionne IJ, Sites CK, Eltabbakh GH, Sims EA, Poehlman ET. What are the physical characteristics associated with a normal metabolic profile despite a high level of obesity in postmenopausal women? J ClinEndocrinolMetab. 2001;86:1020-5

[156] Stefan N, Kantartzis K, Machann J, Schick F, Thamer C, Rittig K, Balletshofer B, Machicao F, Fritsche A, Häring HU. Identification and characterization of metabolically benign obesity in humans. Arch Intern Med. 2008;168:1609-16.

[157] Karelis AD, St-Pierre DH, Conus F, Rabasa-Lhoret R, Poehlman ET. Metabolic and body composition factors in subgroups of obesity: What do we know? J ClinEndocrinolMetab. 2004;89:2569-75.

[158] Karelis AD. Metabolically healthy but obese individuals. Lancet. 2008;372:1281-3.
[159] Calori G, Lattuada G, Piemonti L, Garancini MP, Ragogna F, Villa M, Mannino S, Crosignani P, Bosi E, Luzi L, Ruotolo G, Perseghin G. Prevalence, metabolic features and prognosis of metabolically healthy obese Italian individuals: The Cremona Study. Diabetes Care. 2011;34:210-5.

[160] Beisel WR. History of nutritional immunology: Introduction and overview. J Nut. 1992;122:591-6.

[161] Prentice AM. The thymus: A barometer of malnutrition. $\mathrm{Br}$ J Nutr. 1999;81(5):345-7.

[162] Robson LC, Schwarz MR. Vitamin B6 deficiency and the lymphoid system. II. Effects of vitamin B6 deficiency in utero on the immunological competence of the offspring. Cell Immunol. 1975;16:145-62.

[163] Corman LC. Effects of specific nutrients on the immune response. Selected clinical applications. Med Clin North Am. 1992;69:759-91.

[164] Mittal A, Woodward B, Chandra RK. Involution of thymic epithelium and low serum thymulin bioactivity in weanling mice subjected to severe food intake restriction or severe protein deficiency. Exp Mol Pathol. 1988;48:226-35

[165] Good RA, Lorenz E. Nutrition and cellular immunity. Int J Immuno-pharmacol. 1992;14:361-8.

[166] Golden MHN, Jackson AA, Golden BE. Effect of zinc on thymus of recently malnourished children. Lancet ii. 1977;1057-9.

[167] Beach RS, Gershwin ME, Makishima RK, Hurley LS. Impaired immunologic ontogeny in postnatal zinc deprivation. J Nut. 1980;110:805-15.

[168] Ferguson AC, Lawlor GJ, Neumann CG, Oh W, Steihm ER. Decreased rosette-forming lymphocytes in malnutrition and intrauterine growth retardation. Trop Ped. 1970;85:717-23.

[169] Ferguson AC. Prolonged impairment of cellular immunity in children with intrauterine growth retardation. J Pedia. 1978;93:52-6.

[170] Prentice AM, Cole TJ, Moore SE, Collinson AC. Programming the adult immune system. In Fetal Programming: Influence on Development and Disease in Later Life. Proceedings of the 36th RCOG Study Group, pp. 399-413 [PMS O'Brien, T Wheeler and DJP Barker, editors]. London: John Libby \& Son. 1999.

[171] Malpuech-Brugere C, Nowacki W, Gueux E, Kuryszko J, Rock E, Rayssiguier Y, Mazur A. Accelerated thymus involution in magnesium-deficient rats is related to enhanced apoptosis and sensitivity to oxidative stress. Brit J Nut. 1999;81:405-11.

[172] Kuvibidila S, Dardenne M, Savino W, Lepault F. Influence of iron-deficiency anemia on selected thymus functions in mice: Thymulin biological activity, T-cell subsets, and thymocyte proliferation. Am J Clin Nutr. 1990;51:228- 32.

[173] Dhur A, Galan P, Christides JP, Polier de Courcy G, Preziosi P, Hercberg S. Effect of folic acid deficiency upon lymphocyte subsets from lymphoid organs in mice. Comp Biochem Physiol. 1991;A98:235-40.

[174] Nodera M, Yanagisawa H, Wada O. Increased apoptosis in a variety of tissues of zinc-deficient rats. Life Sci. 2001;69:1639-49.

[175] Mitsumori K, Takegawa K, Shimo T, Onodera H, Yasuhara $\mathrm{K}$, Takahashi M. Morphometric and immune-histochemical studies on atrophic changes in lympho-hematopoietic organs 
of rats treated with piperonyl butoxide or subjected to dietary restriction. Arch Toxicol. 1996;70:809-14.

[176] Lyra JS, Madi K, Maeda CT, Savino W. Thymic extracellular matrix in human malnutrition. J Pathol. 1993;171:231-6.

[177] Parent G, Chevalier P, Zalles L, Sevilla R, Bustos M, Dhenin $\mathrm{J}$, Jambon B. In vitro lymphocyte-differentiating effects of thymulin(Zn-FTS) on lymphocyte subpopulations of severely malnourished children. Am J Clin Nutr. 1994;60:274-8.

[178] Chevalier P, Sevilla R, Zalles L, Sejas E, Belmonte G, Parent G. Study of thymus and thymocytes omn Bolivian preschool children during recovery from severe protein energy malnutrition. J Nutr Immunol. 1994;3:27-39
[179] Yang H, Youm YH, Vandanmagsar B, Rood J, Kumar KG, Butler AA, Dixit VD. Obesity accelerates thymic aging. Blood. 2009;29;114(18):3803-12.

[180] Howard JK, Lord GM, Matarese G. Leptin protects mice from starvation-induced lymphoid atrophy and increases thymic cellularity in ob/ob mice. J Clin Invest. 1999;104(8):1051-59.

[181] Palmer G, Aurrand-Lions M, Contassot E. Indirect effects of leptin receptor deficiency on lymphocyte populations and immune response in $\mathrm{db} / \mathrm{db}$ mice. J Immunol. 2006;177(5):2899-907.

[182] Hale JS, Boursalian TE, Turk GL, Fink PJ. Thymic output in aged mice. Proc Nat Acad Sci USA. 2006;103:8447-52. 